Revta brasil. Bot., São Paulo, V.24, n.3, p.359-363, set. 2001

\title{
Ceramium nitens (Ceramiaceae, Rhodophyta), an uncommon species from Brazil
}

\author{
Note \\ MUTUE TOYOTA FUJII ${ }^{1,4}$, ADILMA L.M. COCENTINO ${ }^{2}$ and SONIA M. B. PEREIRA ${ }^{3}$
}

(received: December 20, 2000; accepted: May 30, 2001)

\begin{abstract}
Ceramium nitens (Ceramiaceae, Rhodophyta), an uncommon species from Brazil). Morphological studies on Ceramium nitens (C. Agardh) J. Agardh, a completely corticated species, were carried out based on specimens rediscovered in Brazil fifty years after its first record. Its occurrence in Brazil was considered doubtful since it had been collected only once since 1945. Ceramium nitens can be recognized by having axial cells entirely covered by cortical cells, except for the cells near the apex, obscuring the nodal and internodal banding thalli, characteristic of most Ceramium species. In this paper the occurrence of Ceramium nitens in Brazil is confirmed and its vegetative and tetrasporangial structures are described in detail and their implications for the taxonomy of the genera Ceramium, Centroceras and Corallophila are discussed. Brief comments on the geographic distribution of C. nitens are also included.
\end{abstract}

RESUMO - (Ceramium nitens (Ceramiaceae, Rhodophyta), uma espécie incomum no Brasil). Estudos morfológicos em Ceramium nitens (C. Agardh) J. Agardh, uma espécie inteiramente corticada, foram desenvolvidos baseados nos espécimes redescobertos no Brasil após 50 anos. Ceramium nitens tinha sido coletada apenas uma vez, em 1945. Sua ocorrência em águas brasileiras tinha sido considerada duvidosa. C. nitens pode ser reconhecida pela presença de células axiais inteiramente cobertas pelas corticais, exceto nas células próximas ao ápice, obscurecendo o talo com nós corticados e entrenós sem corticação, característico da maioria das espécies de Ceramium. A ocorrência de Ceramium nitens no Brasil é confirmada e o desenvolvimento das estruturas vegetativas e tetrasporangiais da espécie é apresentada, fornecendo subsídios para discussão da implicação dessas características na taxonomia dos gêneros Ceramium, Centroceras e Corallophila. Uma breve discussão sobre a distribuição geográfica de Ceramium nitens foi incluída.

Key words - Rhodophyta, Ceramium nitens, morphology, taxonomy, geographic distribution

\section{Introduction}

Ceramium Roth is a widespread genus with morphological variability and taxonomic instability among Rhodophyta (Womersley 1978, Boo \& Lee 1994, Maggs \& Hommersand 1993). This genus is one of the most diverse in the family Ceramiaceae. Around 190 species of Ceramium have been recorded worldwide (Boo \& Lee 1994). Within this family, the tribe Ceramieae (Dumortier) Schmitz includes genera with monosiphonous cylindrical or slightly compressed thalli, with cortication at the nodes which can be intermittent or continuous along the thallus

1. Instituto de Botânica, Seção de Ficologia, Av. Miguel Estéfano 3687, 04301-902 São Paulo, SP, Brazil.

2. Universidade Federal de Pernambuco, Departamento de Oceanografia, Av. Arquitetura s/nº 50670-901 Recife, PE, Brazil.

3. Universidade Federal Rural de Pernambuco, Departamento de Biologia, Av. D. Manuel de Medeiros $\mathrm{s} / \mathrm{n}^{\circ}$, 52171-900 Recife, PE, Brazil.

4. Corresponding author: mfujii@smtp-gw.ibot.sp.gov.br such as Ceramium Roth, Corallophila Weber-van Bosse, and Centroceras Kützing (Dixon 1960, Hommersand 1963, Norris 1993, Womersley 1998).

On the other hand, species of Ceramium are usually recognized by their filamentous branched thalli with axial cells bearing bands of nodal cortical cells which in most species are separated by noncorticated internodal spaces, whereas other species present a nodal cortication that extends virtually throughout the thalli (Womersley 1978). In Brazil, Oliveira (1977) made reference to 14 taxa belonging to Ceramium, including two varieties. All of them have monosiphonous construction and incomplete cortication. The only completely corticated Ceramium species reported for Brazil is Ceramium nitens (C. Agardh) J. Agardh listed by Williams \& Blomquist (1947) from Pernambuco state. However, morphological detail were not included in that account. In consequence, its occurrence in Brazil was considered doubtful (Oliveira 1977), because it had not been collected again since 1945 .

The occurrence of Ceramium nitens in Brazil is confirmed, based on a description of vegetative and 
tetrasporangial structures, and the implications for the taxonomy of the genera Ceramium, Centroceras and Corallophila are discussed.

\section{Material and methods}

The specimens of Ceramium nitens (C. Agardh) J. Agardh were collected at Porto de Galinhas beach, Ipojuca, Pernambuco state, northeastern Brazil (8 ${ }^{\circ} 30^{\prime} \mathrm{S}$ and $34^{\circ} 56^{\prime}$ W) during the summer of 1995, 1996 and the spring of 1997 (figure 1). The plants were found in the intertidal zone on sandstone reefs, epiphytic on Halimeda opuntia (Linnaeus) Lamouroux, Sargassum cymosum C. Agardh and on Bryothamnion seaforthii (Turner) Kützing, and also entangled in the ropes of ship-anchors.

Specimens were preserved in $4 \%$ formalin-seawater solution, sectioned by free hand with a razor blade, and stained with $0.5 \%$ aniline blue acidified with $1 \%$ hydrochloric acid. Voucher specimens have been deposited in Herbaria SP of the Instituto de Botânica, São Paulo, Brazil, and PEUFR of the Universidade Federal Rural de Pernambuco, Recife, Pernambuco, Brazil. Additional specimens from Mexico, deposited in Herbarium UAMIZ, were examined.

\section{Results}

Ceramium nitens (C. Agardh) J. Agardh, 1851, v. 2.1: 130.
Basionym: Ceramium rubrum (Hudson) C. Agardh var. nitens C. Agardh, 1824: 136.

Type locality: Antilles, locality not specified.

Plants deep red to vine-red, brownish red, or yellowish red in color, cartilaginous. Attachment by rhizoids produced by periaxial cells. Main branching alternate to irregular. Last-order branches with tips abruptly tapered, non-forcipate and slightly curved to their axes. Thallus filamentous, segmented, branched, with axial cells bearing bands of nodal cortical cells closely arranged and completely covering the axes, but with internodal spaces discernible near the apices. Upright branches up to $12 \mathrm{~cm}$ high, forming dense and entangled tufts (figures 2-4), showing typical barrel-shaped segments close to base giving a peculiar appearance to the main axes. Mid axial segments $170-455 \mu \mathrm{m}$ long and 280-300 $\mu \mathrm{m}$ wide. A large wedge-like apical cell cuts off 2-3 disc-like axial segments, which initially remain undivided (figure 4). Up to nine periaxial cells are produced from the central cells (figure 5). Nodal cortex develops from periaxial cell. Each periaxial cell cuts off four cells, two acropetally and two basipetally. These cells continue to divide in a similar pattern producing elongate secondary acropetal cells and

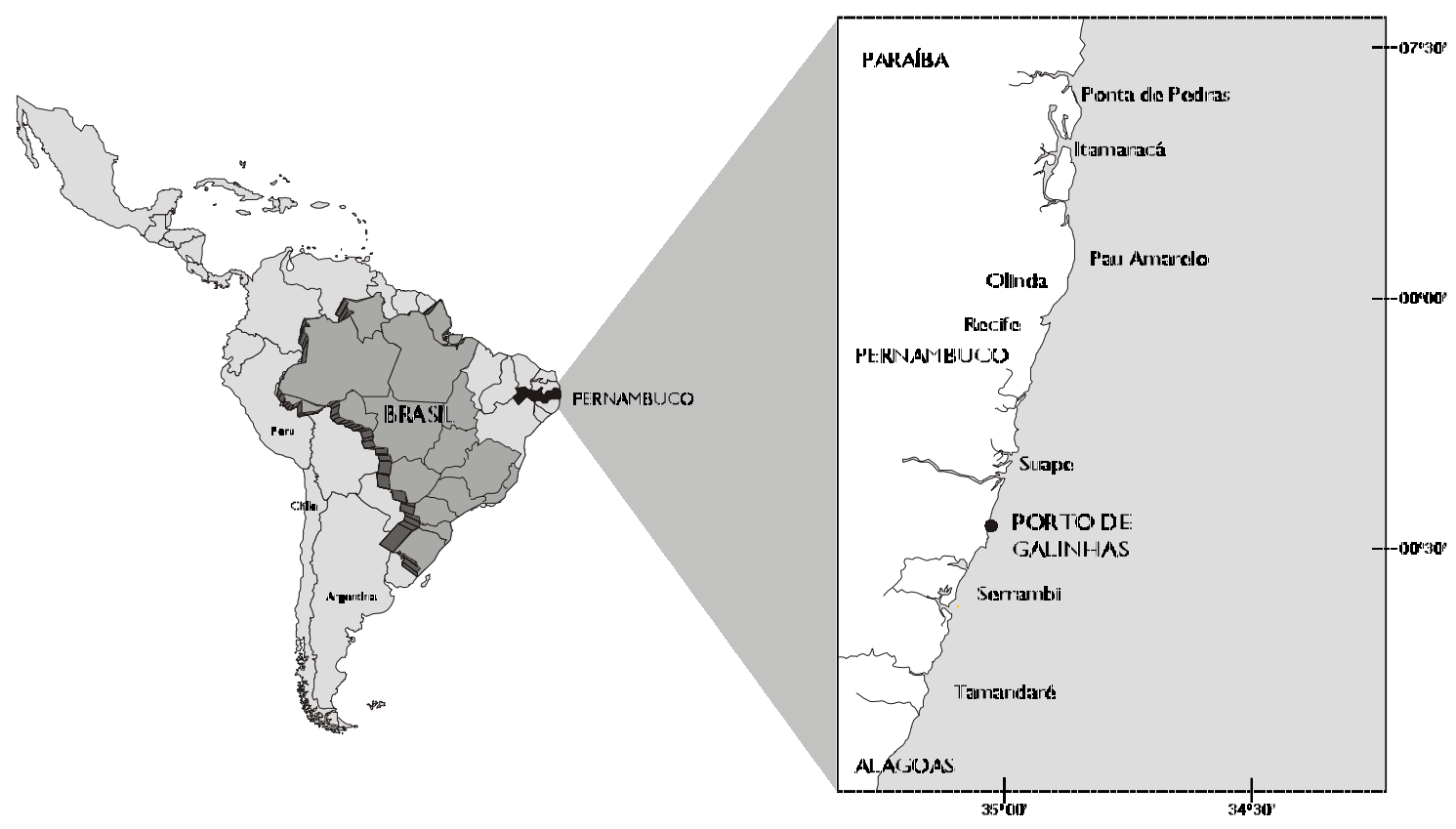

Figure 1. Sampling site at Porto de Galinhas beach, Ipojuca, Pernambuco state, northeastern Brazil. 

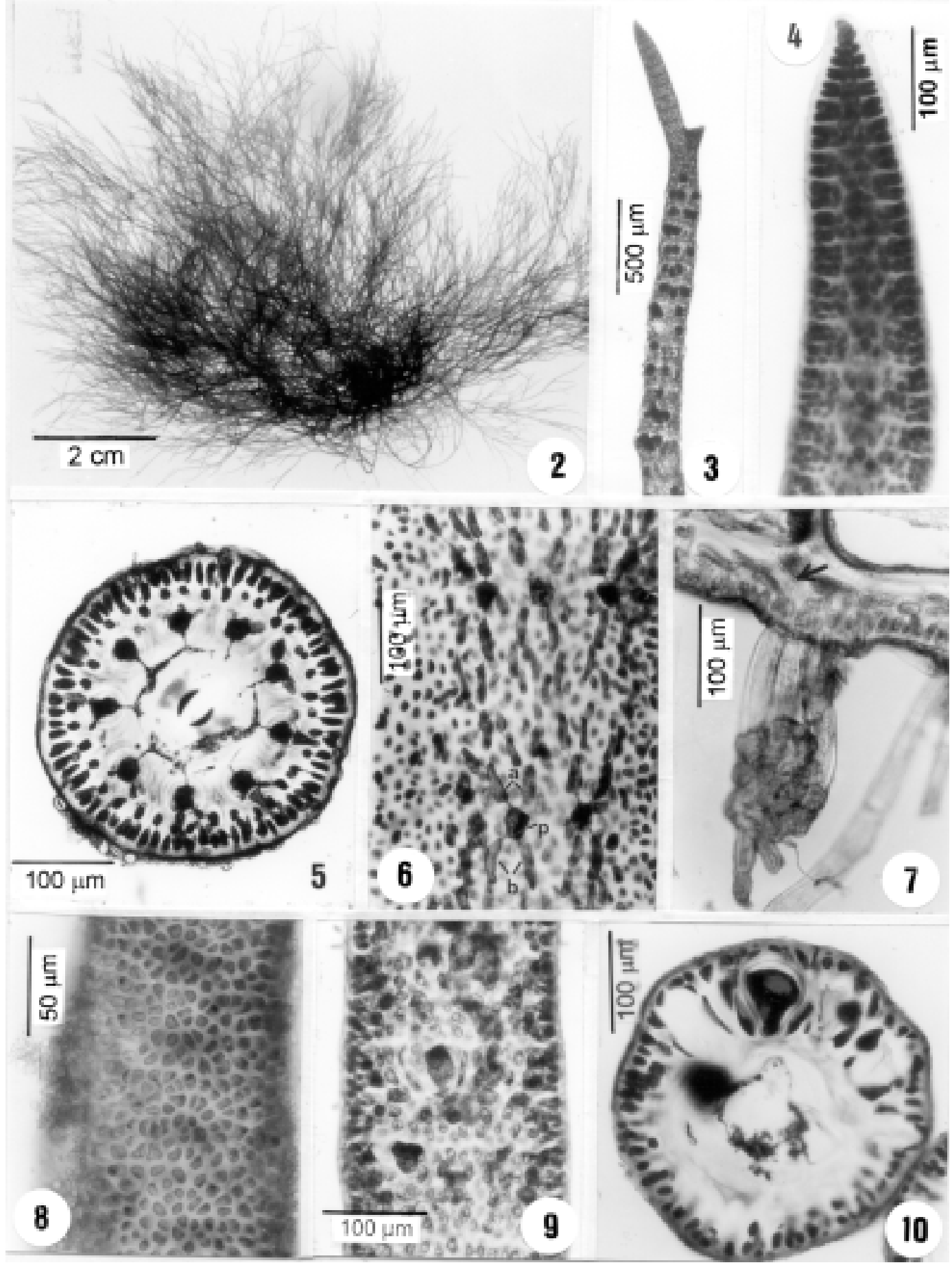

Figures 2-10. Ceramium nitens (C. Agardh) J. Agardh. 2. General aspect of the plant. 3. Detail of the tetrasporangial branch. 4. Apical portion of a branch in superficial view, showing derivative cells from each axial segment. 5. Cross section showing nine periaxial cells originated from axial segment. 6. Superficial view of periaxial cells (p), each with two acropetal (a) and two basipetal (b) cortical filaments. 7. Longitudinal section showing periaxial origin of the rhizoids (arrow). 8. Completely corticated thalli, in superficial view. 9. Detail of tetrasporangial thalli with tetrasporangia immersed in the cortex (superficial view). 10. Cross section of the tetrasporangial thalli showing tetrasporangia originated from periaxial cells. 
round basipetal cells (figures 6, 11-12). Branches and rhizoids originated from periaxial cells (figures 7, 13). In surface view, cortical cells are continuous throughout the thallus (figures 6,8). The banding is recognizable only near the apex (figure 4). Periaxial cells at the middle of the thallus, $35-45 \mu \mathrm{m}$ in diameter; primary acropetal and basipetal cells 20-30 $\mu \mathrm{m}$ long, $13-20 \mu \mathrm{m}$ wide, and cortical cells $15-22 \mu \mathrm{m}$ height, $10-$ $16 \mu$ m wide.

Tetrasporangial plants with tetrahedric tetrasporangia in apical regions of the branches and branchlets (figures 3,9), produced from periaxial cells and whorled at the nodes; they are completely immersed in the thallus (figure 10), with $48-82 \mu \mathrm{m}$ in diameter.

Representative specimens examined: BRAZIL: [PERNANBUCO]; Ipojuca, Porto de Galinhas beach, M.T. Fujii et al. November 1995 (SP 336031); M.T.

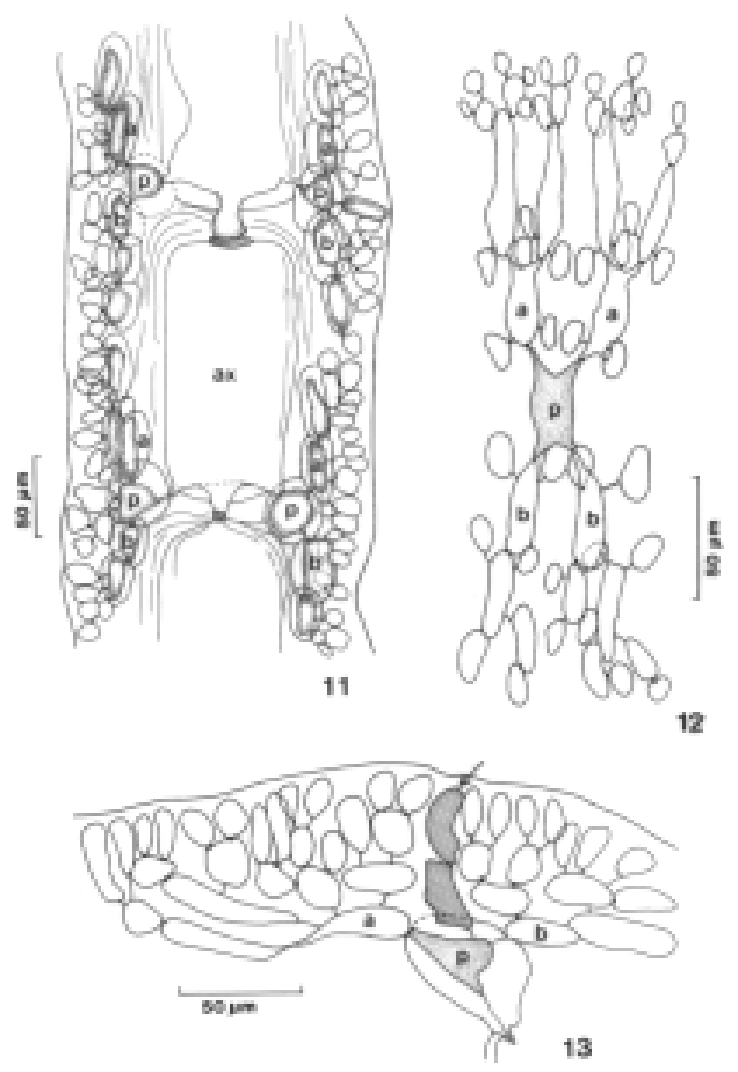

Figures 11-13. Ceramium nitens (C. Agardh) J. Agardh. Diagramatic representations of the derivative cells from each periaxial cell. 11. Longitudinal section, 12. Superficial view. 13. Transverse section. The arrow indicates a rhizoid. $(\mathrm{a}=\mathrm{acropetal}, \mathrm{ax}$ $=$ axial segment, $\mathrm{b}=$ basipetal, $\mathrm{p}=$ periaxial cell $)$.
Fujii \& A.L.M. Cocentino, 12, 1995 (SP 336032); M.T. Fujii, 12, 1996(SP 336033); A.L.M. Cocentino, 10, 1997 (PEUFR 35378).

Additional specimens examined: MEXICO: QUINTANA ROO: Isla Mujeres, M.T. Fujii, January 1996(UAMIZ 901).

Ecology and geographic distribution: Ceramium nitens was originally described from Antilles, Caribbean region as C. rubrum var. nitens and is common on the tropical and subtropical western Atlantic (Taylor 1960, Littler et al. 1989, Wynne 1998, Dreckmann 1998) but uncommon on the Brazilian coast.

In Brazil, $C$. nitens has been reported only from Pernambuco State where the mean annual seawater temperature is around $27.6{ }^{\circ} \mathrm{C}$ as in most Brazilian northeastern coast (figure 1). In this region the main substrate for benthic algae is the sandstone reefs and more rarely the coral reefs and rocky coast. Concerning the water temperature and transparency, this region along the northeastern Brazilian coast is somewhat similar to Caribbean region.

\section{Discussion}

Ceramium nitens shows monopodial growth brought about by a large wedge-like apical cell and adventitious non-dichotomous branching. The periaxial cells cut off two ascending and two descending cortical initial cells, which divide and cover completely the axial filaments. This pattern corresponds to Børgesen's concept of Ceramiella (Børgesen 1953), now assigned to Corallophila (Norris 1993). However, the arrangement of these basipetal cortication cells in non-rectangular parallel longitudinal rows confirms it as a member of Ceramium.

Norris (1993) considered the presence of basipetal cortication with rectangular cells in parallel longitudinal rows, ontogeny of cortex, branch development and reproduction as important diagnostic features to recognize some genera. Within Norris's concept, the species with corticating filaments, only at the nodes or covering the whole axis, by growing mostly in an acropetal direction, are included in Ceramium, while those species with corticating filaments covering entirely the axis by mostly basipetal growth in Corallophila and Centroceras. The distinction between them is based on the presence of three (Centroceras) or four 
(Corallophila) primary corticating filaments produced from each periaxial cell.

Ceramium nitens has periaxial cells with four primary corticating filaments and extensive growth of both acropetal and basipetal filaments, which almost completely cover the axial cells. The corticating filaments in this species are rounded, and never form basipetal rectangular cells in parallel longitudinal rows as members of Centroceras or Corallophila sensu Norris (1993).

The number of periaxial cells per node varies from four to 12 in different species of Ceramium (Dixon 1960, Womersley 1978, Lewis \& Mei-lan 1996) and has limited value to distinguish species. In C. nitens we have observed up to nine periaxial cells per node, whereas J. Agardh (1879) illustrated 12.

In all samples we have examined no gametophytic plants were found, although a lot of tetrasporangial plants have been represented.

Ceramium nitens shows affinity to high temperature waters, and has been reported only in tropical and subtropical regions (Wynne 1998, Dreckmann 1998). Pakker et al. (1995) assigned $C$. nitens as amphi-Atlantic species with a tropical and subtropical distribution, having their northern boundary in the eastern Atlantic at Cape Verde Islands, but also occurring in the Indo-West Pacific.

Littler et al. (1989) stated that a few Ceramium species show a distinctive growth form enough to be identified by the unaided eye such as Ceramium nitens. This is true for the Brazilian specimens, where the reddish tufts of $C$. nitens draw the attention to the reefs of the Porto de Galinhas beach forming well developed populations.

In spite of the widespread distribution in tropical and subtropical waters, in Brazil C. nitens was found only at Porto de Galinhas beach, Pernambuco state, in the same region where it was found for the first time by Williams \& Blomquist (1947). Apparently this region is similar to many other sites along the northeastern Brazilian coast. The reason for such a restricted geographical distribution in Brazil rests unknown.

Acknowledgements - The authors thank Dr. Marcelo Guerra (Universidade Federal de Pernambuco) for logistic support and helping with collection in 1995, and MSc. M. Beatriz B. Barreto (Universidade Federal Rural do Rio de Janeiro) for helpful suggestions. Many thanks also to Dr. Francisco F. Pedroche (Universidad Autónoma Metropolitana - Iztapalapa, México) for critical reading of the manuscript and for improving the English.

\section{References}

AGARDH, J.G. 1879. Florideernes morphologi. Kongliga Svenska Vetenskaps-Akademiens Handlingar, ser. 4, 15(6): 1-199.

BOO, S.M. \& LEE, I.K. 1994. Ceramium and Campylaephora (Ceramiaceae, Rhodophyta). In Biology of economic algae (I. Akatsuka, ed.). SPB Academic Publishing, The Hague, p.1-33.

BØRGESEN, F. 1953. Some marine algae from Mauritius. Additions to the parts previously published, V. Kongelige Danske Videnskabernes Selskab, Biologiske Meddelelser 21:1-62.

DIXON, P.S. 1960. Studies on marine algae of the British Isles: the genus Ceramium. Journal of the Marine Biological Association of the United Kingdom 39:331374.

DRECKMANN, K.M. 1998. Clasificación y nomenclatura de las macroalgas marinas bentonicas del Atlàntico mexicano. CONABIO, México, D.F.

HOMMERSAND, M.H. 1963. The morphology and classification of some Ceramiaceae and Rhodomelaceae. University of California Publications in Botany 35:165366.

LEWIS, J.E. \& MEI-LAN, C. 1996. The species of Ceramium (Ceramiaceae, Rhodophyta) around Taiwan. Hydrobiologia 326/327:149-157.

LITTLER, D.S., LITTLER, M.M., BUCHER, K.E. \& NORRIS, J.N. 1989. Marine plants of the Caribbean: a field guide from Florida to Brazil. Smithsonian Institution Press, Washington.

MAGGS, C.A. \& HOMMERSAND, M.H. 1993. Seaweeds of the British Isles. v. 1. Rhodophyta, part 3A Ceramiales. HMSO Publications, London.

NORRIS, R.E. 1993. Taxonomic studies on Ceramieae (Ceramiales, Rhodophyta) with predominantly basipetal growth of corticating filaments. Botanica Marina 36:389398.

OLIVEIRA FILHO, E.C. 1977. Algas marinhas bentônicas do Brasil. Tese de Livre Docência, Universidade de São Paulo, São Paulo.

PAKKER, H., BREEMAN, A.M., PRUD'HOMME VAN REINE, W.F. \& HOEK, C. VAN DEN. 1995. A comparative study of temperature responses of Caribbean seaweeds from different biogeographic groups. Journal of Phycology 31:499-507.

TAYLOR, W.R. 1960. Marine algae of the eastern tropical and subtropical coasts of the America. University of Michigan Press, Ann Arbor.

WILLIAMS, L.G. \& BLOMQUIST, H.L. 1947. A collection of marine algae from Brazil. Bulletin of the Torrey Botanical Club 74:383-397.

WOMERSLEY, H.B.S. 1978. Southern Australian species of Ceramium Roth Greville (Rhodophyta). Australian Journal of Marine and Freshwater Research 29:205-257.

WOMERSLEY, H.B.S. 1998. The marine benthic flora of southern Australia. Part IIIC, Ceramiales - Ceramiaceae, Dasyaceae. State Herbarium of South Australia, Adelaide.

WYNNE, M.J. 1998. A checklist of benthic marine algae of the tropical and subtropical western Atlantic: first revision. Nova Hedwigia Beiheft 116:1-155. 
